\title{
Bifidobacterium psychraerophilum sp. nov. and Aeriscardovia aeriphila gen. nov., sp. nov., isolated from a porcine caecum
}

Correspondence
Catherine Stanton
cstanton@moorepark.teagasc.ie

\author{
Paul J. Simpson, ${ }^{1}$ R. Paul Ross, ${ }^{1,2}$ Gerald F. Fitzgerald ${ }^{2,3}$ \\ and Catherine Stanton ${ }^{1,2}$ \\ ${ }^{1}$ Teagasc, Dairy Products Research Centre, Moorepark, Fermoy, Co. Cork, Ireland \\ ${ }^{2}$ Alimentary Pharmabiotic Centre, Cork, Ireland \\ ${ }^{3}$ Department of Microbiology, University College Cork, Cork, Ireland
}

\begin{abstract}
In a previous study that was based primarily on $16 \mathrm{~S}$ rDNA sequencing, two groups of bifidobacteria that had been recovered from a pig caecum were proposed to belong to two novel species, termed 'Bifidobacterium pyschroaerophilum' and 'Bifidobacterium aerophilum'. In this study, based on DNA G +C content and partial heat-shock protein 60 (HSP60) gene sequences, the assignment of 'B. pyschroaerophilum', corrected to Bifidobacterium pyschraerophilum, to the genus Bifidobacterium was confirmed. The DNA G+C content of 'B. aerophilum' was relatively low, which was consistent with its segregation into subcluster II of the 16S rDNA phylogenetic tree. Based on partial 16S rDNA and HSP60 gene sequences, the species was transferred to a novel genus and reclassified as Aeriscardovia aeriphila gen. nov., sp. nov. Biochemical profiles and growth parameters were established for both novel species. Interestingly, each had a high tolerance to oxygen and grew on agar media under aerobic conditions, a trait that may relate to their caecal habitat. Under aerobic growth conditions, the short-rod morphology of $A$. aeriphila lengthened considerably. This appeared to arise from incomplete cell division. In addition, $B$. pyschraerophilum was unusual in that it grew at temperatures as low as $4{ }^{\circ} \mathrm{C}$. On the basis of genetic, phylogenetic and phenotypic data, the identities of Bifidobacterium pyschraerophilum sp. nov. (type strain, $\mathrm{T} 16^{\top}=\mathrm{LMG} 21775^{\top}=\mathrm{NCIMB} 13940^{\top}$ ) and Aeriscardovia

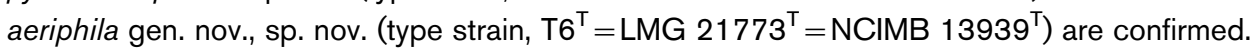

Bifidobacteria are Gram-positive, anaerobic bacteria that are prevalent within the human and animal gastrointestinal tract (GIT) (Langendijk et al., 1995; Sghir et al., 2000; Harmsen et al., 2002). At the time of writing, the genus Bifidobacterium is represented by over 30 species and subspecies, which were mostly recovered from faecal, GIT and sewage samples (Biavati et al., 2000; Hoyles et al., 2002; Jian \& Dong, 2002; Sakata et al., 2002). In a previous study within our laboratory (Simpson et al., 2003), 160 pig caecal isolates were assigned provisionally to the genus Bifidobacterium through detection of fructose-6-phosphate

Published online ahead of print on 12 September 2003 as DOI 10.1099/ijs.0.02667-0.

Abbreviations: FISH, fluorescent in situ hybridization; GIT, gastrointestinal tract; HSP, heat-shock protein.

The GenBank/EMBL/DDBJ accession numbers for the partial HSP60 gene sequences of LMG $21775^{\top}$ (=NCIMB 13940'), LMG $21773^{\top}$ $\left(=\right.$ NCIMB $\left.13939^{\top}\right)$ and LMG 21774 are AY339132, AY339131 and AY339130, respectively.

Phase-contrast and whole-cell FISH images of strains studied in this paper are available as supplementary material in IJSEM Online. phosphoketolase activity (Scardovi, 1986). The isolates were considered to represent 15 strains, based on distinct PFGE macrorestriction patterns; four species were identified, based primarily on $16 \mathrm{~S}$ rDNA sequencing. Two were considered to be novel species and were provisionally termed 'Bifidobacterium pyschroaerophilum' (which consisted of 23 isolates with the same PFGE macrorestriction pattern, termed PFGE type F) and 'Bifidobacterium aerophilum' (which consisted of 77 isolates with three distinct PFGE macrorestriction patterns, termed PFGE types B, E and Ea) (Simpson et al., 2003). 'B. psychroaerophilum' segregated in subcluster I of the 16S rDNA phylogenetic tree, with the majority of Bifidobacterium species. However, 'B. aerophilum' grouped in subcluster II, which was considered previously to represent an undefined genus that was related closely to Bifidobacterium, but with a lower DNA G + C content (Miyake et al., 1998). Indeed, based on heat-shock protein 60 (HSP60) gene sequencing, the two existing species within subcluster II, Bifidobacterium inopinatum and Bifidobacterium denticolens, were transferred to Scardovia gen. nov. and Parascardovia gen. nov., respectively (Jian \& Dong, 2002). 
The DNA $\mathrm{G}+\mathrm{C}$ content of the isolates was determined by HPLC (BCCM/LMG, Belgium) as described by Mesbah et al. (1989). Values reported are means of three measurements on the same DNA. Partial HSP60 gene sequences were obtained by PCR as described by Jian et al. (2001) with the following modifications: the PCR included each primer at $10 \mathrm{pM}$ and $\mathrm{MgCl}_{2}$ at $1 \mathrm{mM}$ and was extended to 35 cycles. The amplicon $(\sim 590 \mathrm{bp})$ was extracted from an agarose gel and sequenced directly by using primers $\mathrm{H} 60 \mathrm{~F}$ and H60R. Analysis of HSP60 gene sequences and phylogenetic tree construction were done as described previously (Simpson et al., 2003). Biochemical profiles for strains from both proposed species were obtained from triplicate tests with the API Rapid ID32A and 20A test strips (bioMérieux). Strains were cultured under anaerobic conditions in modified MRS medium (mMRS), which comprised Lactobacilli MRS medium (Difco) supplemented with $0.05 \%(\mathrm{w} / \mathrm{v})$ cysteine $/ \mathrm{HCl}$, at $37^{\circ} \mathrm{C}$. Growth at low
$\mathrm{pH}$ was determined by using $\mathrm{pH}$-adjusted mMRS (with $\mathrm{HCl}$ ). Growth on mMRS agar under aerobic conditions was determined by streaking cultures and/or spread-plating serial dilutions of overnight anaerobic mMRS broth cultures onto mMRS agar. Selected isolates were deposited with the LMG (BCCM/LMG Bacteria Collection, Laboratorium voor Microbiologie, Universiteit Gent, Belgium) and NCIMB (National Collection of Industrial and Marine Bacteria, Aberdeen, UK) culture collections. High-molecular-mass DNA preparations and PFGE analysis were done as described previously (Simpson et al., 2003), except that cells were removed from the surface of mMRS agar plates. Whole-cell fluorescent in situ hybridization (FISH) was performed on cells from colonies by using an FITClabelled 16S rRNA probe that was specific for either the genus Bifidobacterium or all bacteria (Microscreen; Ribotechnologies). Images were viewed with an Olympus BX51 epifluorescence microscope and captured by using

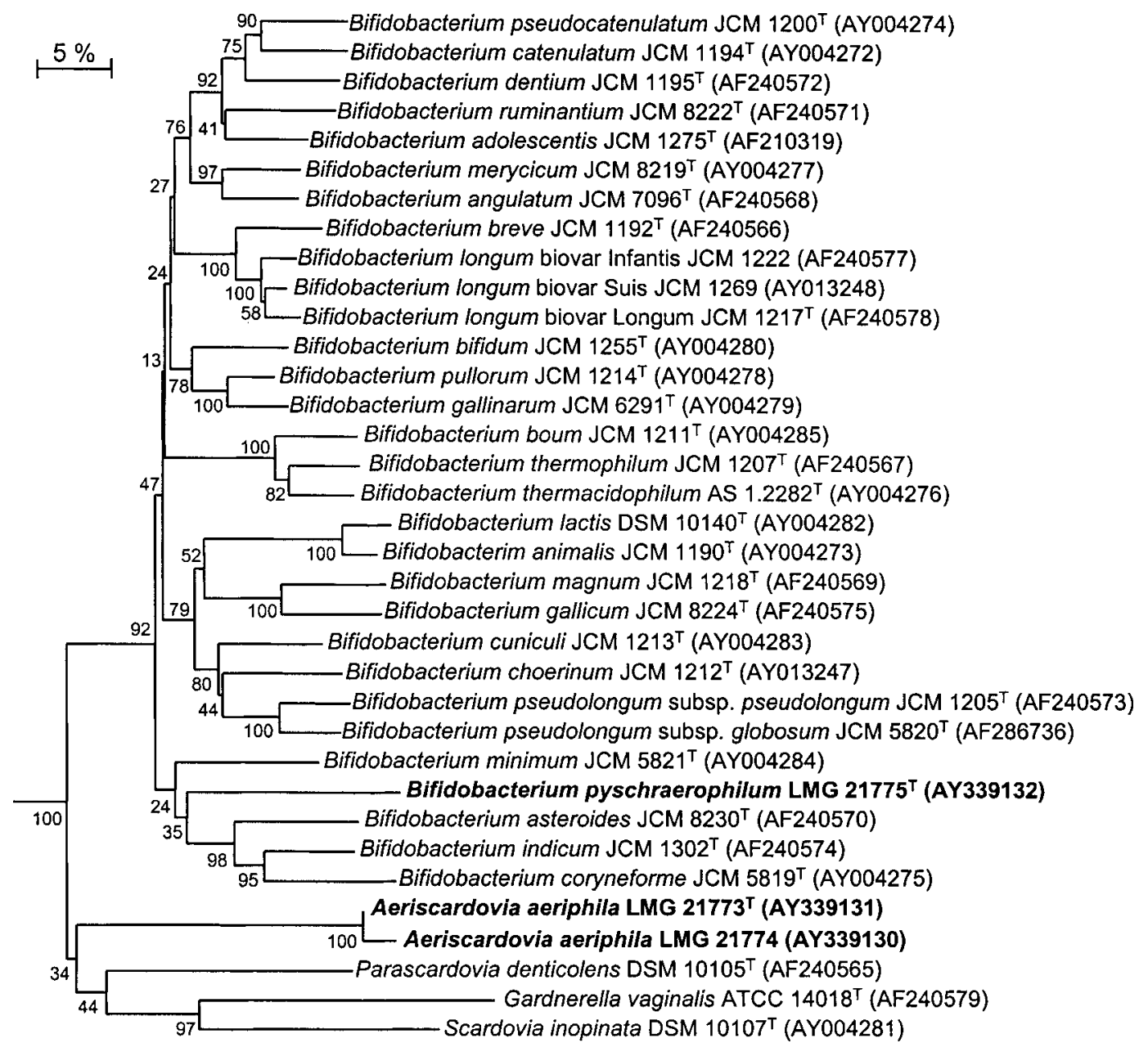

Fig. 1. Phylogenetic tree based on partial HSP60 gene sequences (within the 250-840 nucleotide region). The tree was rooted with Escherichia coli and constructed by using the neighbour-joining method, with bootstrap values calculated from 1000 trees (represented as percentages and given at each branch-point). For each species, the GenBank accession number for their respective HSP60 gene sequence is shown in parentheses. 
an Olympus DP50 digital camera (15 ms exposure for fluorescent images). Cell-size determinations were done as described previously (Simpson et al., 2003).

Isolates $\mathrm{T} 4, \mathrm{~T} 6^{\mathrm{T}}, \mathrm{T} 8$ and $\mathrm{T} 16^{\mathrm{T}}$ were taken as representatives of PFGE types $\mathrm{B}, \mathrm{E}, \mathrm{Ea}$ and $\mathrm{F}$, respectively. Isolate $\mathrm{T} 16^{\mathrm{T}}$ $\left(=\mathrm{LMG} 21775^{\mathrm{T}}\right.$ ) had a DNA G $+\mathrm{C}$ content of $59 \cdot 2 \mathrm{~mol} \%$, which was consistent with the reported range for the genus Bifidobacterium (55-67 mol\%) (Crociani et al., 1996). This concurs with the general grouping of the strain with other Bifidobacterium species within the 16S rDNA (Simpson et al., 2003) and partial HSP60 gene (Fig. 1) phylogenetic trees. In both cases, inclusion of the strain resulted in separation of Bifidobacterium minimum from the three insect-derived species, Bifidobacterium asteroides, Bifidobacterium indicum and Bifidobacterium coryneforme. The highest similarity value for the partial HSP60 gene sequence was $83.58 \%$, which was shared with B. minimum, $B$. asteroides and $B$. indicum. These data support the previous assignment of the strain to the genus Bifidobacterium (Simpson et al., 2003). In the current study, the specific epithet has been corrected to pyschraerophilum. Isolates T4 $(=\mathrm{LMG} 21774)$ and $\mathrm{T}^{\mathrm{T}}\left(=\mathrm{LMG} 21773^{\mathrm{T}}\right)$ had the same DNA G + C content $(54 \cdot 7 \mathrm{~mol} \%)$; this relatively low value is consistent with their grouping with Scardovia inopinata and Parascardovia denticolens in subcluster II of the 16S rDNA phylogenetic tree (Simpson et al., 2003). Based on partial HSP60 gene sequencing, both strains were again clearly related, as they shared $98.44 \%$ sequence similarity. However, isolate $\mathrm{T}^{\mathrm{T}}$ was distinct from the genera Scardovia, Parascardovia and Bifidobacterium, having $71 \cdot 41,71 \cdot 97$ and $73 \cdot 81 \%$ (mean value of $70 \cdot 85-76 \cdot 82 \%$ ) similarity, respectively (Fig. 1). The latter value is comparable to those reported previously for $S$. inopinata and $P$. denticolens (Jian et al., 2001) and we propose that ' $B$. aerophilum' should be transferred to a novel genus. Given the grouping of the novel species in II of the $16 \mathrm{~S}$ rDNA phylogenetic tree, we have termed the novel genus Aeriscardovia gen. nov., in keeping with the taxonomy proposed by Jian \& Dong (2002) and to highlight the aerotolerance of the strains. In accordance with the gender of the proposed genus name, the specific epithet was changed to aeriphila.

Isolates $\mathrm{T} 4, \mathrm{~T} 6^{\mathrm{T}}, \mathrm{T} 8$ and $\mathrm{T} 16^{\mathrm{T}}$ were Gram-positive, catalaseand oxidase-negative, non-spore-forming and non-motile; their respective biochemical profiles are presented in Table 1. For many Bifidobacterium species, carbohydrate profiles are known to vary between strains (Scardovi, 1986; Gómez Zavaglia et al., 1998); this was also apparent for Aeriscardovia aeriphila gen. nov., sp. nov. In addition, given the relatively low number of strains (based on the number of distinct macrorestriction patterns) that are evident within the proposed species, the ability to identify the groups by biochemical profiling can not be stated. No Bifidobacterium species appear to grow at $<20{ }^{\circ} \mathrm{C}$ (Scardovi, 1986; Biavati et al., 2000). However, at 4 and $8{ }^{\circ} \mathrm{C}$, isolate $\mathrm{T} 16^{\mathrm{T}}$ reduced the culture $\mathrm{pH}$ from $\sim 6 \cdot 2$ to
Table 1. Biochemical profiles for strains LMG $21773^{\top}$, LMG 21774, LMG $21775^{\top}$ and isolate T8

Taxa: 1, LMG $21773^{\mathrm{T}}$; 2, T8; 3, LMG 21774; 4, LMG $21775^{\mathrm{T}}$. All strains ferment glucose, salicin, arabinose and raffinose. None ferment rhamnose, trehalose, sorbitol, lactose, mannitol or glycerol. All strains are positive for $\alpha$-galactosidase, $\beta$-galactosidase, $\alpha$-glucosidase, $\beta$-glucosidase, $\alpha$-arabinosidase, arginine arylamidase, proline arylamidase, phenylalanine arlyamidase, leucine arylamidase, tyrosine arylamidase, glycine arylamidase, histidine arylamidase and serine arylamidase activities. All strains are negative for $\beta$-galactosidase-6-phosphate, $\quad \beta$-glucuronidase, $\quad N$-acetyl- $\beta$ glucosaminidase, glutamic acid decarboxylase, alkaline phosphatase, leucyl glycine arylamidase, pyroglutamic acid arylamidase, alanine arylamidase, glutamyl glutamic acid arylamidase and urease activities and indole production. Gelatin is not liquified and nitrate is not reduced to nitrite. + , Positive reaction; $(+)$, weakly positive reaction (negative reaction with the API Rapid ID32A test strip); - , negative reaction.

\begin{tabular}{|lcccc|}
\hline Characteristic & $\mathbf{1}$ & $\mathbf{2}$ & $\mathbf{3}$ & $\mathbf{4}$ \\
\hline Acid from: & & & & \\
Cellobiose & - & - & - & + \\
Maltose & + & + & + & - \\
Mannose & $(+)$ & $(+)$ & $(+)$ & - \\
Melezitose & + & + & - & + \\
Sucrose & - & - & + & + \\
Xylose & - & - & + & + \\
$\alpha$-Fucosidase activity & + & + & + & - \\
\hline
\end{tabular}

$\sim 5.91$ and $\sim 5.46$, respectively, after 16 days incubation, compared to $\sim 4.6$ after $24 \mathrm{~h}$ at $37^{\circ} \mathrm{C}$. Cells cultured at $8{ }^{\circ} \mathrm{C}$ yielded a PFGE macrorestriction pattern that was characteristic for PFGE type F (data not shown). Although sensitivity to oxygen is known to vary between Bifidobacterium species (Scardovi, 1986; Shimura et al., 1992; Meile et al., 1997), no existing species have been reported to grow on agar media under aerobic conditions. However, isolates $\mathrm{T} 4, \mathrm{~T} 6^{\mathrm{T}}$ and $\mathrm{T} 16^{\mathrm{T}}$ all had comparable colony counts following spread-plating on mMRS agar and incubation under aerobic or anaerobic conditions. Based on colony size, growth was clearly reduced in the presence of air. When the type strains for B. minimum, S. inopinata and $P$. denticolens, the nearest neighbours to the novel species (Fig. 1 and Simpson et al., 2003) were streaked onto mMRS agar and incubated aerobically, only B. minimum showed signs of growth. However, growth was limited to the initial inoculation and no individual colonies were observed. Therefore, both novel species appear to be readily distinguished. It is not clear whether the proposed species represent food-associated bacteria that are passing through the GIT or are actual residents of the caecum. Given the relatively high concentration of dissolved oxygen in the pig caecum (Hillman et al., 1993), either habitat could explain their distinctive aerotolerance. Indeed, $\sim 25 \%$ of anaerobes recovered from a human caecum were considered to be facultative anaerobes, compared to only $\sim 0 \cdot 1 \%$ for faecal 
isolates (Marteau et al., 2001). Similarly, bifidobacteria isolated from the chicken crop were considered to have aerotolerant properties (Petr \& Rada, 2001). S. inopinata and $P$. denticolens have an atypical bifidobacterial morphology that is similar to that of isolates $\mathrm{T} 4, \mathrm{~T}^{\mathrm{T}}$ and $\mathrm{T} 8$ (see Supplementary Figure in IJSEM Online, panels $2 \mathrm{a}$ and $4 \mathrm{a}$ ). In addition, for each species, cell morphology changed to an elongated rod with enlarged ends when exposed to oxygen (Crociani et al., 1996; Supplementary Figure, panel $5 a)$. The morphology change was also evident when isolates $\mathrm{T} 4, \mathrm{~T}^{\mathrm{T}}$ and $\mathrm{T} 8$ were cultured at 30 or $46^{\circ} \mathrm{C}$ (data not shown). From whole-cell FISH with a Bifidobacterium genus-specific 16S rRNA probe (Ventura et al., 2001), elongation appeared to be caused by incomplete cell division, resulting in compartmental distribution of the probe (Supplementary Figure, panel 5b). Incomplete cell division was previously considered to be the cause of elongation of cells of Bifidobacterium longum following exposure to oxygen (Ahn et al., 2001). The weak signal observed with strains LMG $21773^{\mathrm{T}}$ and LMG 21774 (Supplementary Figure, panel 2b) may relate to their non-Bifidobacterium status, although the signal was greater than that observed for the negative control culture, Lactobacillus rhamnosus (Supplementary Figure, panel 3b). It is not clear why, when elongated, cells of isolates $\mathrm{T} 4, \mathrm{~T}^{\mathrm{T}}$ and T8 had a strong signal (Supplementary Figure, panel 5b). By using a universal $16 \mathrm{~S}$ rRNA probe, both morphology types yielded equivalent signals (Supplementary Figure, panels $4 \mathrm{~b}$ and $6 \mathrm{~b}$ ), indicating that the weak signal was not related to poor probe penetration into the cells. PFGE patterns obtained from colonies grown under aerobic and anaerobic conditions were identical and characteristic for each strain, indicating that elongation represented an adaptation to stress. No change in cell morphology was seen when strain LMG $21775^{\mathrm{T}}$ was cultured aerobically and an equally strong signal was observed with the Bifidobacterium-specific probe for both aerobically and anaerobically cultured cells. This is consistent with the assignment of the novel species to the genus Bifidobacterium.

The major characteristics that differentiate Bifidobacterium pyschraerophilum sp. nov. and Aeriscardovia aeriphila gen. nov., sp. nov. from other closely related bacteria are summarized in Tables 2 and 3, respectively.

\section{Description of Bifidobacterium psychraerophilum sp. nov.}

Bifidobacterium psychraerophilum (psych.rae.ro'phi.lum. Gr. n. pyschros cold; Gr. n. aēr air; N.L. adj. philus from Gr. adj. philos loving; N.L. neut. adj. psychraerophilum coldand air-loving).

From PFGE analysis, 23 pig caecal isolates appeared to represent a single strain, termed PFGE type F. The following description is based on a single isolate of this strain. Cells are Gram-positive, catalase- and oxidase-negative, non-motile, non-spore-forming, short and irregularly shaped rods, approximately $0 \cdot 7-1 \cdot 0 \mu \mathrm{m}$ wide and $0 \cdot 8-1 \cdot 5 \mu \mathrm{m}$ long with occasional bifurcations, arranged singly or in pairs. Colonies on mMRS agar under anaerobic conditions are white, circular and convex with smooth edges and reach a diameter of up to $3 \mathrm{~mm}$ after 3 days incubation at $37^{\circ} \mathrm{C}$. Colonies are also formed under aerobic conditions, but attain a reduced diameter of $\sim 1 \mathrm{~mm}$ after 3 days incubation. Optimal temperature for growth is $37^{\circ} \mathrm{C}$;

Table 2. Major characteristics that differentiate strain LMG $21775^{\top}$ from phylogenetically related bacteria

Taxa: 1, strain LMG $21775^{\mathrm{T}}$; 2, Bifidobacterium minimum; 3, Bifidobacterium asteroides; 4, Bifidobacterium coryneforme; 5, Bifidobacterium indicum. Data are from this and earlier studies (reviewed by Scardovi, 1986). +, Positive; -, negative; V, variable; ND, not determined.

\begin{tabular}{|lccccc|}
\hline Characteristic & $\mathbf{1}$ & $\mathbf{2}$ & $\mathbf{3}$ & $\mathbf{4}$ & $\mathbf{5}$ \\
\hline Growth on agar medium under aerobic conditions & + & $+^{*}$ & - & - & - \\
Temperature range for growth $\left({ }^{\circ} \mathrm{C}\right)$ & $4-42$ & $22-40$ & $21-42 \dagger$ & $\mathrm{ND}$ & $\mathrm{ND}$ \\
Acid from: & & & & & \\
$\quad$ Maltose & - & + & $\mathrm{V}$ & + & $\mathrm{V}$ \\
Mannose & - & - & $\mathrm{V}$ & - & $\mathrm{V}$ \\
Melezitose & + & - & - & - & - \\
Xylose & + & - & $\mathrm{V}$ & + & - \\
Salicin & + & - & + & + & + \\
Arabinose & + & - & + & + & - \\
Raffinose & + & - & + & + & + \\
Cellobiose & + & - & + & + & + \\
DNA G+C content $(\mathrm{mol} \%)$ & $59 \cdot 2$ & $61 \cdot 5$ & 59 & $\mathrm{ND}$ & 60 \\
\end{tabular}

${ }^{\star}$ Growth limited to the initial streak on mMRS agar medium.

$\uparrow$ No growth at these temperatures. 
Table 3. Major characteristics that differentiate strains LMG $21773^{\top}$ and LMG 21774 from phylogenetically related genera

Taxa: 1, strain LMG $21773^{\mathrm{T}}$; 2, strain LMG 21774; 3, Bifidobacterium; 4, Scardovia; 5, Parascardovia. Data are from this and earlier studies (Scardovi, 1986; Gavini et al., 1991; Crociani et al., 1996; Jian \& Dong, 2002). +, Positive; (+), weakly positive; -, negative; V, variable; ND, not determined.

\begin{tabular}{|lcccccc|}
\hline Characteristic & $\mathbf{1}^{*}$ & $\mathbf{2}$ & $\mathbf{3}$ & $\mathbf{4}$ & $\mathbf{5}$ \\
\hline Growth on agar medium under aerobic conditions & + & + & $(+) \dagger$ & - & - \\
Temperature range for growth $\left({ }^{\circ} \mathrm{C}\right)$ & $30-46$ & $30-46$ & $25-46$ & $27-44$ & $27-44$ \\
Elongated cell morphology on exposure to oxygen & + & + & $\mathrm{V}$ & + & + \\
Acid from: & & & & & \\
Maltose & + & + & $\mathrm{V}$ & + & + \\
Mannose & $(+)$ & $(+)$ & $\mathrm{V}$ & - & - \\
Melezitose & - & + & $\mathrm{V}$ & $\mathrm{V}$ & - \\
Sucrose & + & - & + & + & + \\
Xylose & + & - & $\mathrm{V}$ & + & - \\
Salicin & + & + & $\mathrm{V}$ & $\mathrm{V}$ & + \\
Arabinose & + & + & $\mathrm{V}$ & - & $\mathrm{V}$ \\
Raffinose & + & + & $\mathrm{V}$ & $\mathrm{V}$ & $\mathrm{V}$ \\
Trehalose & - & - & $\mathrm{V}$ & - & $\mathrm{V}$ \\
Sorbitol & - & - & $\mathrm{V}$ & $\mathrm{ND}$ & $\mathrm{ND}$ \\
Lactose & - & - & $\mathrm{V}$ & $\mathrm{V}$ & + \\
Mannitol & - & - & $\mathrm{V}$ & - & - \\
Cellobiose & - & - & $\mathrm{V}$ & - & + \\
DNA G + C content $(\mathrm{mol} \%)$ & $54 \cdot 7$ & $54 \cdot 7$ & $55-67$ & 45 & 55 \\
\hline
\end{tabular}

${ }^{\star}$ Isolate T8 (PFGE type Ea) had the same characteristic profile as strain LMG $21773^{\mathrm{T}}$ (PFGE type E). $\dagger$ Bifidobacterium minimum grows at the initial inoculation point on mMRS agar.

maximum temperature for growth is $42{ }^{\circ} \mathrm{C}$, with no growth at $46^{\circ} \mathrm{C}$. Growth occurs at $4{ }^{\circ} \mathrm{C}$, although it is considerably reduced. Lowest $\mathrm{pH}$ attained is $4 \cdot 0$, with a minimum initial $\mathrm{pH}$ for growth of $4 \cdot 5$. DNA G $+\mathrm{C}$ content is $59 \cdot 2 \mathrm{~mol} \%$. Biochemical characteristics are shown in Table 1.

Type strain is $\mathrm{T}^{\mathrm{T}} \mathrm{T}^{\mathrm{T}}$ (PFGE type $\left.\mathrm{F}\right)\left(=\mathrm{LMG} 21775^{\mathrm{T}}=\right.$ NCIMB $13940^{\mathrm{T}}$ ). Isolated from a pig caecum (contents and epithelium) in Fermoy, Ireland. Previously termed 'Bifidobacterium pyschroaerophilum'.

\section{Description of Aeriscardovia gen. nov.}

Aeriscardovia (Aer'i.scar.do'vi.a. L. masc. n. aer, aeris air; N.L. fem. n. Scardovia a bacterial generic name to honour Vittorio Scardovi, an Italian microbiologist; N.L. fem. n. Aeriscardovia cells similar to the genus Scardovia that can grow in air).

Gram-positive, catalase- and oxidase-negative, non-motile, non-spore-forming, short and irregularly shaped rods. Optimal growth occurs under anaerobic conditions, with aerobic growth yielding elongated cells. DNA G $+\mathrm{C}$ content of the type species is $54 \cdot 7 \mathrm{~mol} \%$. Isolated from a porcine caecum. According to $16 \mathrm{~S}$ rDNA and HSP60 gene sequence comparisons, Aeriscardovia belongs to the family Bifidobacteriaceae. Only one species, the type species Aeriscardovia aeriphila, has thus far been described.

\section{Description of Aeriscardovia aeriphila sp. nov.}

Aeriscardovia aeriphila (L. masc. n. aer, aeris air; Gr. adj. philos loving; N.L. fem. adj. aeriphila air-loving).

From PFGE analysis, 77 pig caecal isolates appeared to represent three strains, termed PFGE types B, E and Ea. The following phenotypic description is based on a representative isolate for each strain. Cells are Gram-positive, catalase- and oxidase-negative, non-motile, non-sporeforming, short and irregularly shaped rods, approximately $0 \cdot 6-0.9 \mu \mathrm{m}$ wide and $0 \cdot 8-1 \cdot 5 \mu \mathrm{m}$ long, that are arranged singly or in pairs, but not in chains. Colonies on mMRS agar under anaerobic conditions are grey-white, circular and flat to convex with entire edges and reach a diameter of up to $3 \mathrm{~mm}$ after 3 days incubation at $37^{\circ} \mathrm{C}$. Colonies are also formed under aerobic conditions, but a diameter of only $\sim 1 \mathrm{~mm}$ is attained after 5 days incubation. Under aerobic conditions, cell morphology includes elongated cells of approximately 4-6 $\mu \mathrm{m}$ in length. Optimum temperature for growth is $37^{\circ} \mathrm{C}$, with a maximum of $46^{\circ} \mathrm{C}$ and minimum of $30^{\circ} \mathrm{C}$. No growth occurs at 48 or $25^{\circ} \mathrm{C}$. In mMRS, the lowest $\mathrm{pH}$ value attained is $4 \cdot 2$; minimum initial $\mathrm{pH}$ for growth is $4 \cdot 5$. DNA G $+\mathrm{C}$ content of strains of PFGE types $\mathrm{B}$ and $\mathrm{E}$ is $54 \cdot 7 \mathrm{~mol} \%$. Biochemical characteristics are shown in Table 1. A single plasmid of $30 \mathrm{kbp}$ may be present in isolates of PFGE type Ea, based on macrorestriction pattern data. 
Type strain is $\mathrm{T}^{\mathrm{T}}$ (PFGE type E) (=LMG $21773^{\mathrm{T}}=$ NCIMB $13939^{\mathrm{T}}$ ). Isolated from a pig caecum (contents and epithelium) in Fermoy, Ireland. Previously termed 'Bifidobacterium aerophilum'.

\section{Acknowledgements}

This work was supported by the Irish Government under the National Development Plan 2000-2006, Science Foundation Ireland and the European Union (SM\&T-CT98-2235).

\section{References}

Ahn, J. B., Hwang, H.-J. \& Park, J.-H. (2001). Physiological responses of oxygen-tolerant anaerobic Bifidobacterium longum under oxygen. J Microbiol Biotechnol 11, 443-451.

Biavati, B., Vescovo, M., Torriani, S. \& Bottazzi, V. (2000). Bifidobacteria: history, ecology, physiology and applications. Ann Microbiol 50, 117-131.

Crociani, F., Biavati, B., Alessandrini, A., Chiarini, C. \& Scardovi, V. (1996). Bifidobacterium inopinatum sp. nov. and Bifidobacterium denticolens sp. nov., two new species isolated from human dental caries. Int J Syst Bacteriol 46, 564-571.

Gavini, F., Pourcher, A.-M., Neut, C., Monget, D., Romond, C., Oger, C. \& Izard, D. (1991). Phenotypic differentiation of bifidobacteria of human and animal origins. Int J Syst Bacteriol 41, 548-557.

Gómez Zavaglia, A., Kociubinski, G., Pérez, P. \& De Antoni, G. (1998). Isolation and characterization of Bifidobacterium strains for probiotic formulation. J Food Prot 61, 865-873.

Harmsen, H. J. M., Raangs, G. C., He, T., Degener, J. E. \& Welling, G. W. (2002). Extensive set of $16 \mathrm{~S}$ rRNA-based probes for detection of bacteria in human feces. Appl Environ Microbiol 68, 2982-2990.

Hillman, K., Whyte, A. L. \& Stewart, C. S. (1993). Dissolved oxygen in the porcine gastrointestinal tract. Lett Appl Microbiol 16, 299-302.

Hoyles, L., Inganäs, E., Falsen, E., Drancourt, M., Weiss, N., McCartney, A. L. \& Collins, M. D. (2002). Bifidobacterium scardovii sp. nov., from human sources. Int J Syst Evol Microbiol 52, 995-999.

Jian, W. \& Dong, X. (2002). Transfer of Bifidobacterium inopinatum and Bifidobacterium denticolens to Scardovia inopinata gen nov., comb. nov., and Parascardovia denticolens gen. nov., comb nov., respectively. Int J Syst Evol Microbiol 52, 809-812.

Jian, W., Zhu, L. \& Dong, X. (2001). New approach to phylogenetic analysis of the genus Bifidobacterium based on partial HSP60 gene sequences. Int J Syst Evol Microbiol 51, 1633-1638.
Langendijk, P. S., Schut, F., Jansen, G. J., Raangs, G. C., Kamphuis, G. R., Wilkinson, M. H. F. \& Welling, G. W. (1995). Quantitative fluorescence in situ hybridization of Bifidobacterium spp. with genus-specific $16 \mathrm{~S}$ rRNA-targeted probes and its application in fecal samples. Appl Environ Microbiol 61, 3069-3075.

Marteau, P., Pochart, P., Doré, J., Béra-Maillet, C., Bernalier, A. \& Corthier, G. (2001). Comparative study of bacterial groups within the human cecal and fecal microbiota. Appl Environ Microbiol 67, 4939-4942.

Meile, L., Ludwig, W., Rueger, U., Gut, C., Kaufmann, P., Dasen, G., Wenger, S. \& Teuber, M. (1997). Bifidobacterium lactis sp. nov., a moderately oxygen tolerant species isolated from fermented milk. Syst Appl Microbiol 20, 57-64.

Mesbah, M., Premachandran, U. \& Whitman, W. B. (1989). Precise measurement of the $\mathrm{G}+\mathrm{C}$ content of deoxyribonucleic acid by highperformance liquid chromatography. Int J Syst Bacteriol 39, 159-167.

Miyake, T., Watanabe, K., Watanabe, T. \& Oyaizu, H. (1998). Phylogenetic analysis of the genus Bifidobacterium and related genera based on 16S rDNA sequences. Microbiol Immunol 42, 661-667.

Petr, J. \& Rada, V. (2001). Bifidobacteria are obligate inhabitants of the crop of adult laying hens. J Vet Med Ser B 48, 227-234.

Sakata, S., Kitahara, M., Sakamoto, M., Hayashi, H., Fukuyama, M. \& Benno, Y. (2002). Unification of Bifidobacterium infantis and Bifidobacterium suis as Bifidobacterium longum. Int J Syst Evol Microbiol 52, 1945-1951.

Scardovi, V. (1986). Genus Bifidobacterium. In Bergey's Manual of Systematic Bacteriology, vol. 2, pp. 1418-1434. Edited by P. H. A. Sneath, N. S. Mair, M. E. Sharpe \& J. G. Holt. Baltimore: Williams \& Wilkins.

Scardovi, V. \& Trovatelli, L. D. (1974). Bifidobacterium animalis (Mitsuoka) comb. nov. and the "minimum" and "subtile" groups of new bifidobacteria found in sewage. Int J Syst Bacteriol 24, 21-28.

Sghir, A., Gramet, G., Suau, A., Rochet, V., Pochart, P. \& Doré, J. (2000). Quantification of bacterial groups within human fecal flora by oligonucleotide probe hybridization. Appl Environ Microbiol 66, 2263-2266.

Shimura, S., Abe, F., Ishibashi, N., Miyakawa, H., Yaeshima, T., Araya, T. \& Tomita, M. (1992). Relationship between oxygen sensitivity and oxygen metabolism of Bifidobacterium species. J Dairy Sci 75, 3296-3306.

Simpson, P. J., Stanton, C., Fitzgerald, G. F. \& Ross, R. P. (2003). Genomic diversity and relatedness of bifidobacteria isolated from a porcine cecum. J Bacteriol 185, 2571-2581.

Ventura, M., Elli, M., Reniero, R. \& Zink, R. (2001). Molecular microbial analysis of Bifidobacterium isolates from different environments by the species-specific amplified ribosomal DNA restriction analysis (ARDRA). FEMS Microbiol Ecol 36, 113-121. 